\title{
Gene Recombination in Postmitotic Cells \\ Targeted Expression of Cre Recombinase Provokes Cardiac-restricted, Site-specific Rearrangement in Adult Ventricular Muscle In Vivo
}

\author{
Ramtin Agah, ${ }^{\star \ddagger}$ Peter A. Frenkel, ${ }^{\star \ddagger}$ Brent A. French, ${ }^{\mathbb{1}}$ Lloyd H. Michael,, Paul A. Overbeek, ${ }^{\S}$ and Michael D. Schneider ${ }^{\ddagger} \|$ \\ * Molecular Cardiology Unit, ${ }^{\ddagger}$ Department of Medicine, ${ }^{\S}$ Department of Cell Biology, and $\|^{D}$ Department of Molecular Physiology and \\ Biophysics, Baylor College of Medicine, Houston, Texas 77030; and "Molecular Cardiology Unit, Department of Medicine, University of \\ Louisville Health Science Center, Louisville, Kentucky 40292
}

\begin{abstract}
Mouse models of human disease can be generated by homologous recombination for germline loss-of-function mutations. However, embryonic-lethal phenotypes and systemic, indirect dysfunction can confound the use of knock-outs to elucidate adult pathophysiology. Site-specific recombination using Cre recombinase can circumvent these pitfalls, in principle, enabling temporal and spatial control of gene recombination. However, direct evidence is lacking for the feasibility of Cre-mediated recombination in postmitotic cells. Here, we exploited transgenic mouse technology plus adenoviral gene transfer to achieve Cre-mediated recombination in cardiac muscle. In vitro, Cre driven by cardiac-specific $\alpha$-myosin heavy chain ( $\alpha \mathrm{MyHC})$ sequences elicited recombination selectively at loxP sites in purified cardiac myocytes, but not cardiac fibroblasts. In vivo, this $\alpha \mathrm{MyHC}-\mathrm{Cre}$ transgene elicited recombination in cardiac muscle, but not other organs, as ascertained by PCR analysis and localization of a recombination-dependent reporter protein. Adenoviral delivery of Cre in vivo provoked recombination in postmitotic, adult ventricular myocytes. Recombination between loxP sites was not detected in the absence of Cre. These studies demonstrate the feasibility of using Cre-mediated recombination to regulate gene expression in myocardium, with efficient induction of recombination even in terminally differentiated, postmitotic muscle cells. Moreover, delivery of Cre by viral infection provides a simple strategy to control the timing of recombination in myocardium. $(J$. Clin. Invest. 1997. 100:169-179.) Key words: adenovirus • cardiac muscle $\bullet$ Cre recombinase $\cdot$ homologous recombination • transgenic mice
\end{abstract}

\section{Introduction}

Gene targeting to generate loss-of-function mutations in the mouse has yielded remarkable advances in understanding the roles played by specific gene products in mammalian develop-

R. Agah and P.A. Frenkel contributed equally to this work.

Address correspondence to Dr. Michael D. Schneider, Molecular Cardiology Unit, One Baylor Plaza, Room 506C, Baylor College of Medicine, Houston, TX 77030. Phone: 713-798-6683; FAX: 713-7987437; E-mail: michaels@bcm.tmc.edu

Received for publication 23 September 1996 and accepted in revised form 31 March 1997.

J. Clin. Invest.

(C) The American Society for Clinical Investigation, Inc.

0021-9738/97/07/0169/11 \$2.00

Volume 100, Number 1, July 1997, 169-179 ment and, to a lesser extent, human disease (1). Inherent impediments, however, can complicate the use of conventional homologous recombination to elicit the role of genes in adult pathophysiology. For example, illustrated by the retinoblastoma protein (2), deletion of a protein which also serves essential functions in embryogenesis can result in early lethality, precluding the use of germline mutations to investigate the protein's function in any adult context. Other potential effects confounding conventional knock-outs include the risk of impaired fertility and generalized, systemic disorders, illustrated by knock-out mutations of transforming growth factor beta-1 (TGF $\beta 1$ ): the ability to test specific hypotheses regarding the role of TGF $\beta 1$ in adult disease is impeded by the animals' multifocal immunological disorders, poor viability, and absolute requirement for an immunodeficient background; coadministration of immunosuppressive drugs; or both $(3,4)$. Related constraints are foreseeable for receptors or intracellular proteins that are required for TGF $\beta$ effects. Thus, given that germline mutations might not permit a definitive loss-of-function study in a specific adult context, methods to achieve gene inactivation in a regulatable or tissue-restricted manner are desired. Both yeast (5-7) and phage (8-18) site-specific recombinases have been used to achieve targeted recombination of mammalian genes. Thus, regulated expression of recombinase, in turn, can be used, in principle, to achieve tissue-restricted and/or stage-specific recombination to induce or inactivate predetermined genes.

Cre recombinase, from the $\mathrm{P} 1$ bacteriophage, has proven efficacious in mediating recombination in mammalian cells (8-18). The 38-kD Cre protein functions as a site-specific recombinase, splicing DNA between specific 34 bp sequences known as loxP sites. Each loxP site contains a dyad of $13 \mathrm{bp}$, separated by an 8 -bp spacer that gives $5^{\prime}$ to $3^{\prime}$ orientation to the motif. Cre is capable of catalyzing three forms of recombination: excision, inversion, and integration, dictated by the orientation of loxP sites relative to each other. Excision or inversion occur when the loxP sites exist on the same strand of DNA (as direct versus inverted repeats, respectively); insertion can occur, using loxP sites on separate strands.

Cre-mediated recombination can be regulated by controlling the timing or spatial distribution of Cre expression via tissue-specific promoters (17), ligand-inducible promoters (18), and ligand-dependent Cre fusion proteins (16). Kühn et al. (18) deleted a DNA polymerase $\beta$ gene, flanked by loxP sites (floxed), by expressing Cre in transgenic mice using an IFNdependent promoter, the Mx1 promoter. Densitometric analyses of Southern blots suggest that $100 \%$ of the pol $\beta$ alleles in liver and spleen were deleted after induction of Cre expression. Importantly, $65 \%$ of the allele was lost in cardiac tissue as well. This work provides preliminary evidence that Cre-mediated recombination can take place in adult myocardium, con- 
taining terminally differentiated muscle cells in which DNA synthesis ordinarily cannot occur, but relies on a Southern blot that does not establish whether recombination occurred in the postmitotic myocytes, versus the abundant populations of interstitial fibroblasts and other nonmuscle cells that largely comprise the adult heart; e.g., $\sim 85 \%$ nonmyocytes in murine heart (19). The same limitation applies to a recent report demonstrating the utility of Flp recombinase in transgenic mice, where a $30 \%$ recombination frequency in DNA extracted from skeletal muscle leaves substantial room for doubt concerning the identity of cell types involved (7). Despite the attractiveness of site-directed recombination for applications affecting terminally differentiated lineages such as cardiac or skeletal muscle, to date there has not yet been a definitive, direct test for the feasibility of site-directed recombination in an irreversibly postmitotic muscle cell.

Here, both a cardiac-specific promoter of Cre recombinase and an injection of recombinant adenoviruses (20) have been used to direct Cre expression in mouse myocardium: Cremediated recombination was found to occur both in cultured neonatal cardiac myocytes and the intact adult heart. These studies establish the utility of targeting Cre to myocardium, to achieve gene recombination even in postmitotic ventricular muscle cells.

\section{Methods}

Construction of the $\alpha M y H C$-Cre gene. The nuclear-localized Cre expression vector, pOG231 (provided by S. O'Gorman, Salk Institute, La Jolla, CA), was digested with SacI and HindIII, removing the cytomegalovirus $(\mathrm{CMV})^{1}$ promoter but retaining the ATG start site and SV40 nuclear localization signal (nls; CCCAAGAAGAAGAGGAAGGTG $=$ PKKKRKV) in frame with the first codon of Cre cDNA $($ TTC $=S)$. The cardiac-specific murine $\alpha$-myosin-heavy chain (MyHC) promoter ( $\alpha-5.5$, provided by J. Robbins, University of Cincinnati, Cincinnati, $\mathrm{OH})(21)$ was ligated as a SacI-HindIII fragment $180 \mathrm{bp}$ upstream from the nls-Cre translational start site. The resulting $\alpha \mathrm{MyHC}$-Cre expression vector comprises the $\beta \mathrm{MyHC} 3^{\prime}$ untranslated region, $\alpha \mathrm{MyHC}$ promoter, $\alpha \mathrm{MyHC}$ noncoding exons 1 and 2 (with the corresponding introns), and exon 3 splice acceptor sequence, $180 \mathrm{bp}$ upstream from the nls-Cre ATG start site.

Cell culture and transfection. Primary cultures of $2 \mathrm{~d}$ postnatal Sprague-Dawley rat cardiac myocytes and cardiac fibroblasts were prepared using enzymatic dissociation, Percoll purification, and serum-free medium containing DME/Hams medium F12 (1:1), $5 \mu \mathrm{g} \cdot \mathrm{ml}^{-1}$ transferrin, $1 \mathrm{nM} \mathrm{Na} 2 \mathrm{SeO} 4,1 \mathrm{nM} \mathrm{LiCl}$, and $25 \mu \mathrm{g} \cdot \mathrm{ml}^{-1}$ ascorbic acid (22). Cells were plated at a density of $2 \times 10^{5}$ cells per $7 \mathrm{~mm}$ well for adenoviral infection and $9 \times 10^{5}$ cells per $35 \mathrm{~mm}$ well for DNA-mediated gene transfer. Transfection of neonatal cardiac myocytes and cardiac fibroblasts was carried out using lipofectamine, $1.0 \mu \mathrm{g}$ of the loxP-tagged CAG-CATZ reporter (23), $0.5 \mu \mathrm{g}$ of an SV40-driven luciferase reporter gene to correct for transfection efficiency, and $2.0 \mu \mathrm{g}$ of the test vector (pcDNA3, the CMV promoter alone; OG231, CMV-driven Cre recombinase; 11120 , the $\alpha$ MyHC promoter alone; or $\alpha \mathrm{MyHC}$-driven Cre). Cells were incubated for $4.5 \mathrm{~h}$ at $37^{\circ} \mathrm{C}$ in the lipofectamine/DNA solution, for $8 \mathrm{~h}$ in DME/Hams medium F12 (1:1) supplemented with $5 \%$ horse serum, and for $60 \mathrm{~h}$ in the serum-free medium, with the addition of $1 \mathrm{nM} \mathrm{T3}$.

Transgenic mice. The $\alpha$ MyHC-Cre gene was excised from the

1. Abbreviations used in this paper: CAT, chloramphenicol acetyltransferase; CMV, cytomegalovirus; MyHC, myosin-heavy chain; PFU, plaque-forming units; X-gal, 5-bromo-4-chloro-3-indolyl- $\beta$-D galactopyranoside. plasmid vector backbone using SacI and KpnI. A 6.9-kbp fragment of pCAG-CATZ (23), containing the $\beta$-actin promoter, loxP-tagged chloramphenicol acetyltransferase (CAT) gene, and adjacent LacZ gene, was excised using SalI and PstI. DNA fragments were separated by electrophoresis through $1 \%$ agarose, and purified using Qiaex II reagents (QIAGEN Inc., Chatsworth, CA). The linear $\alpha \mathrm{MyHC}-\mathrm{Cre}$ and CAG-CATZ genes were microinjected separately into the pronuclei of FVB/N zygotes (24), at a concentration of $2 \mathrm{ng} / \mu \mathrm{l}$ in $10 \mathrm{mM}$ Tris- $\mathrm{HCl}$ ( $\mathrm{pH} 7.4), 0.1 \mathrm{M}$ EDTA, and injected embryos were transferred to pseudopregnant ICR females.

Recombinant adenoviruses. Construction of Ad5/CMV/nls-LacZ, which directs the expression of Escherichia coli LacZ, fused to the nuclear localization signal of SV40 large T antigen, has been reported previously (25). Ad5/CMV was created by subcloning the 1,276-bp BgIII-PvuII fragment containing the CMV immediate early promoter, polylinker, and bovine growth hormone polyadenylation site from pcDNA3 (Invitrogen Corp., San Diego, CA) between the unique BgIII and Klenow-blunted ClaI sites of the adenoviral shuttle vector $\mathrm{p} \Delta \mathrm{E} 1 \mathrm{sp} 1 \mathrm{~B}(26)$. The resulting plasmid ( $\mathrm{p} \Delta \mathrm{E} 1 \mathrm{sp} 1 \mathrm{~B} / \mathrm{CMV})$ was then cotransfected with pJM17 into permissive 293 host cells to generate Ad5/CMV by standard methods (27). AdCre (containing the CMV-driven Cre recombinase) and AdMA19 (containing the firefly luciferase reporter gene separated from the CMV promoter by a loxP-flanked $1.3 \mathrm{kbp}$ spacer) were generously provided by Dr. Frank Graham, McMaster University, Hamilton, Ontario (28); the spacer region of AdMA19 contains stop codons in all three reading frames. All adenoviruses were propagated in 293 cells, harvested, cesium chloride-purified, and titered as described (27). Cardiac cells were infected with recombinant adenoviruses, after $24 \mathrm{~h}$ in serum-free medium, for $4 \mathrm{~h}$ at moi ranging from 0 to 300 plaque forming units (PFU) per cell, using $200 \mu$ l of virus in DME per well. The viral solution then was aspirated from each culture and replaced with $1 \mathrm{ml}$ of serum free media for $48 \mathrm{~h}$.

In vivo gene transfer to mouse myocardium. Mice were anesthetized by intramuscular injection using $10 \mu \mathrm{l} / \mathrm{g}$ of $4 \mathrm{mg} / \mathrm{ml}$ pentobarbital sodium in $20 \%$ ethanol, supplemented with $3 \mu \mathrm{l} / \mathrm{g}$ as needed. Mice were intubated using a PE-90 endotracheal tube and ventilated using a small animal Harvard respirator (rate, 90-100 per min; tidal volume, 3-5 ml). Connection of the respirator to the PE-90 tubing was formed with PE-160 tubing to ensure a loose fit and prevent barotrauma by lung overexpansion (29). The skin overlying the sternum was incised, midline vessels of the sternum cauterized using bovie forceps, and the sternum divided. The sternum was retracted using 6-0 ligatures, and the heart was gently exteriorized using Crile forceps at the apex. Care was taken not to damage the lungs or great vessels in the process. The heart was briefly immobilized between the thumb and index finger of the operator and was injected at the apex over $\sim 2 \mathrm{~s}$ with $100 \mu \mathrm{l}$ of PBS $\left(130 \mathrm{mM} \mathrm{NaCl}, 15 \mathrm{mM} \mathrm{Na}_{2} \mathrm{HPO}_{4}, 15 \mathrm{mM}\right.$ $\mathrm{NaH}_{2} \mathrm{PO}_{4}, 1 \mathrm{mM} \mathrm{MgCl}$, and $1 \mathrm{mM} \mathrm{CaCl}_{2}$ ) containing the virus, using a Hamilton syringe equipped with a 31-gauge needle. The heart was then returned to the thoracic cavity and the sternum was closed. Over the next 15-30 min, upon return of spontaneous movement, the mice were removed from the ventilator and provided with $100 \% \mathrm{O}_{2}$, with spontaneous respiration resuming within 15-30 s. Body temperature was maintained during these procedures using a heat lamp, and $100 \%$ $\mathrm{O}_{2}$ was provided through a nose cone.

For initial validation studies, 12-wk-old ICR mice (35-40 g, Harlan Sprague Dawley, Inc., Indianapolis, IN) were inoculated with $10^{10}$ PFU of Ad5/CMV/nls-LacZ $(n=5)$ versus Ad/CMV $(n=2)$ or the diluent $(n=2)$, and were killed at 7 d. For the AdCre plus AdMA19 coinjection studies, ICR mice were injected with $6 \times 10^{7} \mathrm{PFU}$ of AdCre $(n=2), 6 \times 10^{7}$ PFU of AdMA19 $(n=3)$, both viruses each at $6 \times 10^{7}$ PFU $(n=7)$, or $6 \times 10^{7} \mathrm{PFU}$ of Ad/CMV/nls-LacZ $(n=2)$. For Cre activation of CAG-CATZ in transgenic mice, 9.5-wk-old mice were injected with $2 \times 10^{8} \mathrm{PFU}$ of AdCre $(n=3)$ or of $\operatorname{Ad} / \mathrm{CMV}(n=2)$.

Biochemical assays. Luciferase activity was monitored as the oxidation of luciferin in the presence of coenzyme A, using an Analytical Luminescence model 2010 luminometer (30). LacZ activity was de- 
termined using chlorophenol red- $\beta$-D-galactosidase as substrate (31). Total protein was measured by the Bradford method (32). CAT activity was measured by the phase-extraction method (33) with $25 \mu \mathrm{g}$ of $n$-butyryl coenzyme A, $24 \mu \mathrm{M}$ D-threo-di-chloroacetyl-1,2 $\left[{ }^{14} \mathrm{C}\right]$ chloramphenicol (DuPont-NEN, Boston, MA), and $100 \mu$ l of lysate in 25 $\mathrm{mM}$ Tris- $\mathrm{HCl}, \mathrm{pH} 7.4$, using a Beckman LS6800 scintillation counter. For biochemical determinations of reporter gene activity in vivo, hearts were washed and homogenized for $15 \mathrm{~s}$ using a Tissumizer (Wheaton Science Products, Millville, NJ), in $250 \mu \mathrm{l}$ per $100 \mathrm{mg}$ of $25 \mathrm{mM}$ Tris phosphate, $\mathrm{pH}$ 7.8, $2 \mathrm{mM}$ dithiothreitol, $2 \mathrm{mM}$ EDTA, $10 \%$ glycerol, and $1 \%$ Triton X-100, containing $1 \mathrm{mg} / \mathrm{ml}$ Pefabloc SC, $0.5 \mathrm{mg} / \mathrm{ml}$ EDTA, $10 \mu \mathrm{g} / \mathrm{ml}$ leupeptin, $10 \mu \mathrm{g} / \mathrm{ml}$ pepstatin, and $1 \mu \mathrm{g} / \mathrm{ml}$ aprotinin as protease inhibitors. Homogenates were centrifuged at $10,000 \mathrm{~g}$ for $10 \mathrm{~min}$ at room temperature, and the supernatants were analyzed as described above for cultured cells.

Western blot analysis. For immunodetection of luciferase protein, cardiac myocytes were infected, as detailed above, with AdCre, AdMA19, or AdMA19 plus AdCre at an moi of 15 for each virus. Cell lysates $(50 \mu \mathrm{g}$ of protein per lane) were resolved by electrophoresis through a $10 \%$ sodium dodecyl sulfate-polyacrylamide gel, in parallel with $300 \mathrm{ng}$ of purified firefly luciferase (Boehringer Mannheim Biochemicals, Indianapolis, IN) as a positive control. Proteins were transferred electrophoretically to a $2-\mu \mathrm{m}$ nylon membrane (BioRad Laboratories, Richmond, CA), using 0.1 M cyclohexylaminopropane sulfonic acid: $10 \%$ methanol. The membrane was rinsed with buffer D (500 mM NaCl, $20 \mathrm{mM}$ Tris- $\mathrm{HCl}, \mathrm{pH} 7.5,0.3 \%$ Tween 20$)$ and incubated for $1 \mathrm{~h}$ at room temperature with a polyclonal rabbit antibody directed against luciferase (Cortex, San Leano, CA), using a $1: 4,000$ dilution in buffer D plus $0.2 \%$ fatty acid-free BSA. The membrane then was washed for $30 \mathrm{~min}$ at room temperature with $3 \times 50 \mathrm{ml}$ of buffer D containing 3\% Tween 20, incubated for $1 \mathrm{~h}$ at room temperature with secondary antibody (horseradish peroxidase-conjugated donkey antibody against rabbit IgG; Amersham Corp., Arlington Heights, IL), using a 1:10,000 dilution in buffer D plus $0.2 \%$ fatty acid-free BSA, and washed with $3 \times 50 \mathrm{ml}$ of buffer D plus $3 \%$ Tween 20. Bound antibody was detected by chemiluminescence, using ECL reagents (Amersham Corp.).

PCR analysis. To demonstrate Cre-mediated recombination after transient transfection, using PCR, myocytes were harvested using $0.02 \%$ trypsin in PBS, and were incubated in $100 \mathrm{mM}$ Tris- $\mathrm{HCl}, \mathrm{pH}$ 7.5, $10 \mathrm{mM}$ EDTA, $0.5 \%$ sodium dodecyl sulfate, $1 \mathrm{mg} / \mathrm{ml}$ proteinase $\mathrm{K}$ for $1 \mathrm{~h}$ at $56^{\circ} \mathrm{C}$. DNA was extracted in phenol/chloroform and was ethanol-precipitated. Oligonucleotides were synthesized corresponding to the $3^{\prime}$ end of the chicken $\beta$-actin promoter (5'-CTGCTAACCATGTTCATGCC-3'; AG2) and $5^{\prime}$ end of the LacZ gene (5'-GGCCTCTTCGCTATTACG-3'; Z3). PCR analysis was performed using Taq polymerase and $1 \mu \mathrm{g}$ of DNA from each myocyte transfection in a $50-\mu \mathrm{l}$ reaction mixture containing $500 \mathrm{mM} \mathrm{KCl}, 100 \mathrm{mM}$ Tris- $\mathrm{HCl}, \mathrm{pH}$ 9.0, $1.5 \mathrm{mM} \mathrm{MgCl}_{2}, 1 \%$ Triton X-100, and $0.6 \mathrm{mM}$ dNTPs. DNA was denatured at $94^{\circ} \mathrm{C}$ for $1 \mathrm{~min}$; primers were annealed at $60^{\circ} \mathrm{C}$ for $1 \mathrm{~min}$ and extended at $72^{\circ} \mathrm{C}$ for $1 \mathrm{~min}$ for 32 cycles. Elongation time for the PCR reaction was selected to prevent amplification of the intact, 2,000-bp segment, while permitting amplification of the recombined, 690-bp segment (see Fig. 1).

Presence of the CAG-CATZ transgene was assessed by amplification of genomic DNA from tail samples, using a sense primer at the $5^{\prime}$ end and antisense primer for the mid-portion of CAT cDNA, respectively (5'-CAGTCAGTTGCTCAATGTACC-3'; 5'-ACTGGTGAAACTCACCGA-3'), and resulting in a 320-bp band. Primers were annealed at $60^{\circ} \mathrm{C}$ for $1 \mathrm{~min}$ and extended at $72^{\circ} \mathrm{C}$ for $1 \mathrm{~min}$ for 30 cycles. To identify $\alpha \mathrm{MyHC}$-Cre transgenic mice, a sense primer positioned at the $3^{\prime}$ end of intron 2 of the $\alpha \mathrm{MyHC}$ promoter (5'-ATGACAGACAGATCCCTCCTATCTCC-3') was used with an antisense primer at the $5^{\prime}$ end of the Cre coding region (5'-CTCATCACTCGTTGCATCATCGAC-3'), to amplify a 300-bp fragment. The primers were annealed at $59^{\circ} \mathrm{C}$ for $1 \mathrm{~min}$, with extension at $72^{\circ} \mathrm{C}$ for 1 min, for 30 cycles of amplification. Conditions otherwise were those shown for PCR analysis of DNA from cultured cells.
For PCR analysis of Cre-mediated recombination in vivo, the primers, buffer, and conditions were identical to those used for recombination in the transiently transfected cells, except DNA samples were isolated from heart, liver, lung, skeletal muscle (quadriceps), or spleen at the time of necropsy. As a positive control, $\beta$-casein was amplified, using the following primers (sense, 5'-GATGTGCTCCAGGCTAAAGTT-3'; antisense, 5'-AGAAACGGAATGTTGTGGAGT-3').

Histochemistry. For histological detection of reporter gene expression after injection of recombinant viruses, hearts were bisected, mounted in freezing medium, and frozen in liquid nitrogen, with exceptions where noted below. Sets of 4-6 $\mu \mathrm{m}$ cryostat sections were obtained, spaced at $250 \mu \mathrm{m}$ intervals using a coronal plane of section, and were fixed in $4 \%$ formaldehyde for $10 \mathrm{~min}$. At each interval, one section was used for hematoxylin-eosin staining and one for 5-bromo4-chloro-3-indolyl- $\beta$-D galactopyranoside (X-Gal) staining (34), counterstained with nuclear fast red. The percentage of X-Gal-positive cells was estimated for each section, using cell number from the adjacent hematoxylin-eosin-stained section as the denominator.

For luciferase immunocytochemistry, tissue sections fixed as above were incubated with $0.3 \% \mathrm{H}_{2} \mathrm{O}_{2}$ in methanol to inactivate endogenous peroxidase activity, then were incubated with the antiluciferase antibody at a dilution of 1:75 in PBS plus 1\% BSA. Sections were incubated overnight in a humidifying chamber at room temperature and washed three times. Bound primary antibody was visualized using biotinylated goat antibody against rabbit $\mathrm{IgG}$, followed by avidin conjugated to horseradish peroxidase (Santa Cruz Biotechnology, Santa Cruz, CA). Sections were incubated in diaminobenzidine/ $10 \%$ hydrogen peroxide (Pierce, Rockford, IL) for 10 min and counterstained with eosin.

To detect Cre-dependent $\beta$-galactosidase expression by wholeorgan staining, tissues were harvested from 6-wk-old animals and fixed for $2 \mathrm{~h}$ at room temperature in $2 \%$ formaldehyde, $0.2 \%$ glutaraldehyde, $0.2 \%$ Nonidet P- $40,5 \mathrm{mM}$ ethylenebis(oxyethylenenitrilo)tetraacetic acid, $2 \mathrm{mM} \mathrm{MgCl}, 0.1 \mathrm{M}$ sodium phosphate ( $\mathrm{pH}$ 7.3). Samples were rinsed for $3 \times 30 \mathrm{~min}$ at room temperature in $0.1 \%$ deoxycholate, $0.2 \%$ Nonidet $\mathrm{P}-40,2 \mathrm{mM} \mathrm{MgCl}, 0.1$ sodium phosphate ( $\mathrm{pH} 7.3)$, stained for $3 \mathrm{~h}$ at room temperature with $1 \mathrm{mg} / \mathrm{ml} \mathrm{X-gal}$ (Boehringer Mannheim Biochemicals), $5 \mathrm{mM} \mathrm{K}_{4} \mathrm{Fe}(\mathrm{CN})_{6}, 5 \mathrm{mM}$ $\mathrm{K}_{3} \mathrm{Fe}(\mathrm{CN})_{6}, 0.1 \%$ deoxycholate, $0.2 \%$ Nonidet P- $40,2 \mathrm{mM} \mathrm{MgCl}_{2}, 0.1$ sodium phosphate ( $\mathrm{pH} 7.3$ ), and rinsed twice with PBS (35).

Statistics. Statistical analysis was performed using ANOVA and Scheffe's multiple comparison test, using a significance level of $P<$ 0.05 .

\section{Results}

A cardiac-specific Cre vector mediates recombination selectively in cultured ventricular muscle cells. To achieve cardiac myocyte-restricted expression of Cre recombinase, Cre cDNA was placed under the transcriptional control of the cardiacspecific $\alpha \mathrm{MyHC}$ promoter (21). In parallel experiments, cultured ventricular myocytes versus ventricular fibroblasts were cotransfected with the Cre-dependent reporter gene CAGCATZ (23), together with the CMV promoter alone, CMVdriven Cre, $\alpha \mathrm{MyHC}$ promoter alone, or $\alpha \mathrm{MyHC}$-driven Cre promoter (Fig. 1). CAG-CATZ harbors a CAT gene flanked by loxP sites and driven by the chicken $\beta$-actin promoter (23); downstream of CAT is the E. coli $\beta$-galactosidase gene (LacZ; Fig. $1 \mathrm{~A}$ ). In the absence of Cre, the CAT gene prevents readthrough expression of LacZ. Conversely, when the CAT gene is excised by Cre-mediated recombination between the tandem loxP sites, LacZ becomes positioned adjacent to the $\beta$-actin promoter, permitting LacZ expression. The CMV promoter was able to direct Cre-mediated recombination effectively in both cell types. By contrast, $\alpha \mathrm{MyHC}$-Cre was active selec- 
A.

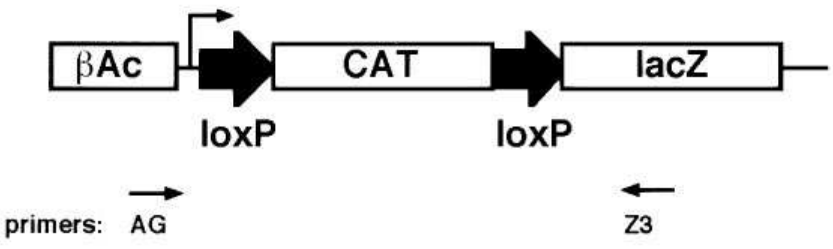

B.

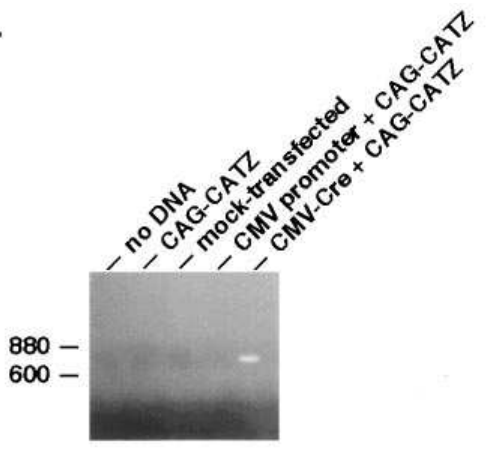

C. Myocytes: LacZ

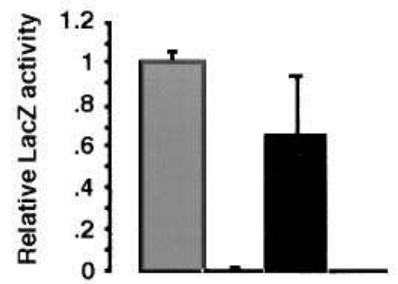

D. Fibroblasts: LacZ

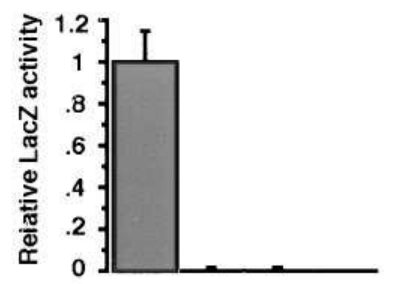

E. Fibroblasts: CAT

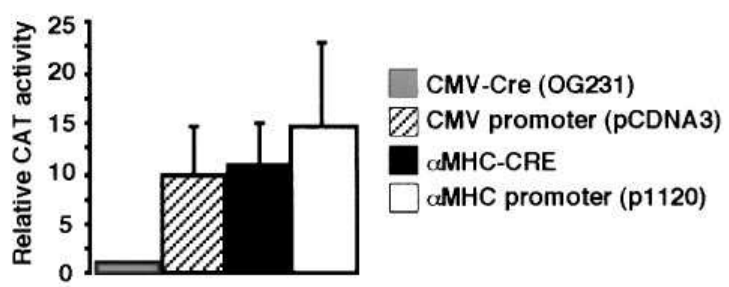

Figure 1. An $\alpha$ MyHC-driven Cre vector mediates recombination in cardiac muscle cells in vitro. $(A)$ Schematic of pCAG-CATZ. The PCR primers, AG and Z3, flank the paired loxP sites and internal CAT gene. (B) PCR analysis. Cardiac myocytes were transfected with pCAGCATZ and CMV-Cre as indicated. DNA was isolated $60 \mathrm{~h}$ after transfection, and was assayed for the appearance of the recombinationdependent 690-bp fragment. $(C)$ Neonatal rat ventricular myocytes ventricular fibroblasts were cotransfected with $1 \mu \mathrm{g}$ pCAG-CATZ and $0.5 \mu \mathrm{g}$ of an SV40-driven luciferase reporter gene (to correct for transfection efficiency), in the presence or absence of a Cre expression vector, as shown to the right of $E$; (gray) CMV-Cre, (hatched) CMV promoter, (black) $\alpha \mathrm{MyHC}$-Cre, (white) $\alpha \mathrm{MyHC}$ promoter. Cells were harvested $60 \mathrm{~h}$ after transfection. Results (mean \pm SEM, $n=13$ for each condition shown), adjusted for the cotransfected luciferase gene, are expressed relative to CMV-Cre-transfected cells. Induction of LacZ by $\alpha \mathrm{MyHC}-\mathrm{Cre}$ in cardiac muscle cells was roughly two-thirds of that obtained with the constitutive CMV-Cre vector. $(D)$ Cardiac fibroblasts were cotransfected as described for $C$. By contrast, LacZ expression was induced only by the CMV-Cre construct, and not the $\alpha$ MyHC-driven Cre gene. $(E)$ Transfected cardiac fibroblasts also were analyzed for CAT expression. The loxP-flanked CAT gene was downregulated $\sim 90 \%$ by CMV-Cre, relative to cells cotransfected with pCAG-CATZ plus the CMV promoter.

tively, provoking gene recombination only in the ventricular myocytes (Fig. 1, $C$ and $D$ ). Adequate transfection of fibroblasts was verified both by the cotransfected luciferase control, and by the capacity of CAG-CATZ to function in this background, as verified by CAT activity of the unmodified CAGCATZ reporter (Fig. 1 E). Thus, Cre-mediated recombination can occur in neonatal ventricular myocytes.

To validate the above results, Cre-mediated recombination at the loxP sites was assessed using PCR (Fig. $1 \mathrm{~B}$ ). No recombination was detected when cardiac myocytes were cotransfected with CAG-CATZ and the control expression vector containing the CMV promoter alone. Thus, the appearance of LacZ protein and the predicted recombination event were each contingent on the delivery of Cre recombinase. Spontaneous recombination, while theoretically possible between the paired loxP sites, occurs under these conditions, if at all, at a frequency too low to be detected by PCR. The results shown in Fig. $1 B$ establish the Cre-dependence and appropriate size for the recombined gene in preparation for in vivo work, to be discussed below, and do not address the frequency for in vitro recombination, which is not germane to this report.

The $\alpha M y H C$-Cre transgene directs cardiac-restricted recombination in CAG-CATZ mice. To establish the feasibility of cardiac-restricted recombination in vivo, the $\alpha \mathrm{MyHC}-\mathrm{Cre}$ construct was used to generate transgenic mice, and Cre-dependent reporter mice likewise were generated, using the chimeric
CAG-CATZ gene described above. Transgene-positive mice were identified by PCR, using primers specific for each construct, respectively. 2 of 21 potential $F_{0}$ mice carried the CAGCATZ gene; nine of 38 potential $\mathrm{F}_{0}$ mice bore the $\alpha \mathrm{MyHC}-\mathrm{Cre}$ gene. The CAG-CATZ founders 2104 and 2112 and $\alpha \mathrm{MyHC}$ Cre founder 2182 were arbitrarily selected for further characterization here. To establish that the CAG-CATZ reporter was transcriptionally competent in adult myocardium, tissue extracts from $F_{1}$ progeny were analyzed for expression of the CAT gene. As anticipated, the loxP-flanked CAT gene was highly active in myocardium and other organs of CAG$\mathrm{CATZ}^{+}$mice, whereas the LacZ gene, distal to the second loxP site, was silent (data not shown).

To test for Cre-mediated recombination of the CAG-CATZ target gene, CAG-CATZ $F_{1}$ mice and $\alpha \mathrm{MyHC}-\mathrm{Cre} \mathrm{F}_{0}$ mice were mated. As shown by PCR analysis (Fig. 2), the $\alpha \mathrm{MyHC}-\mathrm{Cre}$ and CAG-CATZ transgenes each were inherited by roughly half the progeny, and two of the eight littermates received both genes. Myocardial recombination of the CAG-CATZ gene, assayed using the primers shown in Fig. $1 A$, occurred only in the $\alpha \mathrm{MyHC}-\mathrm{Cre}^{+} / \mathrm{CAG}-\mathrm{CATZ}^{+}$double transgenic mice (Fig. 2 A, top). Recombination was cardiac-restricted and contingent on the presence of both transgenes concomitantly (Fig. 2 B, bottom). No background or spontaneous recombination was detected.

To demonstrate the functional consequences of Cre-depen- 

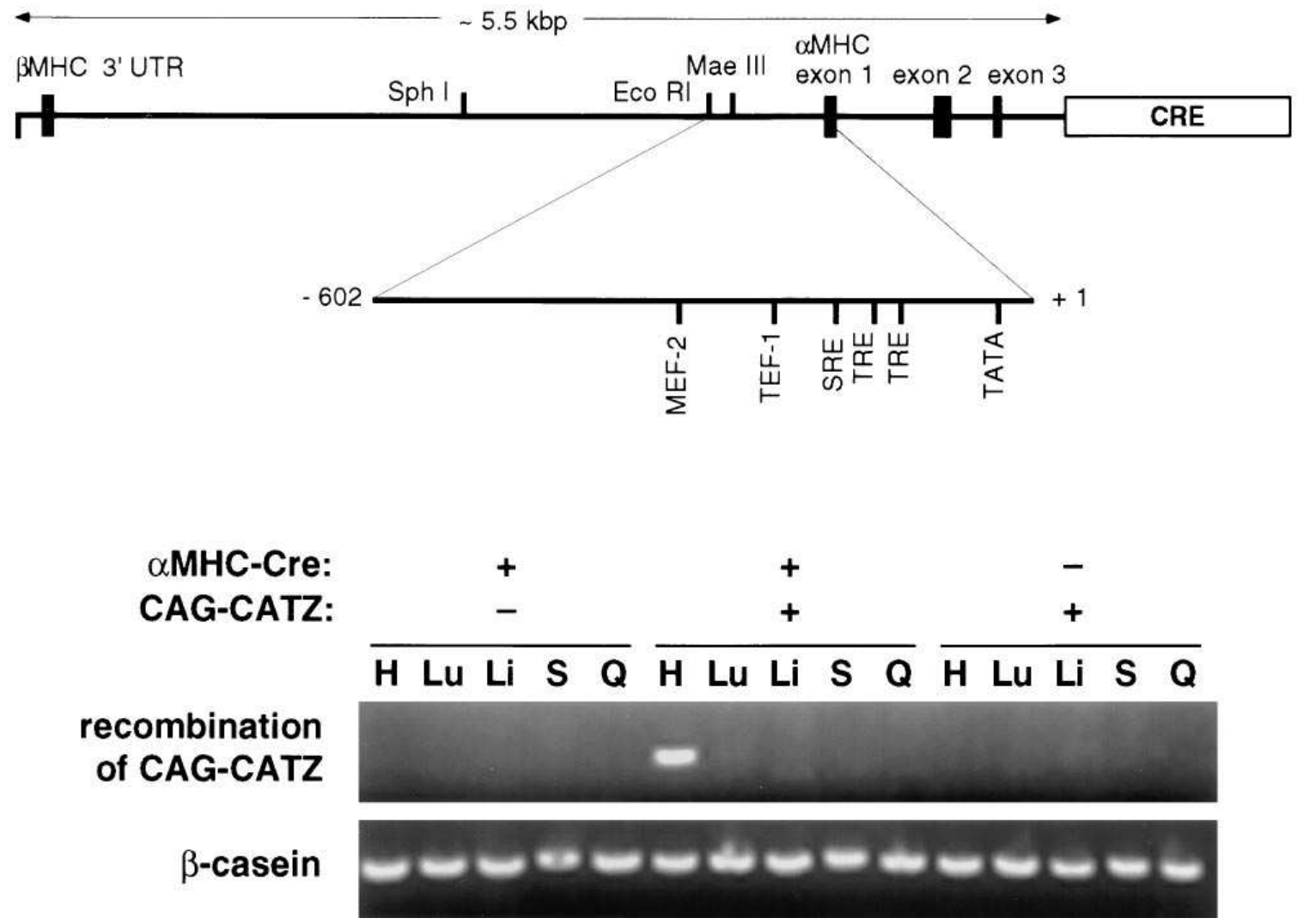

Figure 2. Cardiac-restricted recombination in $\alpha \mathrm{MyHC}-\mathrm{Cre} \times \mathrm{CAG}-\mathrm{CATZ}$ transgenic mice. (Top) Structure of the $\alpha \mathrm{MyHC}$-Cre construct. (Bottom) PCR analysis of representative littermates from the mating of an $\alpha \mathrm{MyHC}_{-} \mathrm{Cre}^{+}$mouse to a CAG-CATZ ${ }^{+}$mouse. To define the genotype of each animal, tail DNA was analyzed for the presence of the $\alpha$ MyHC-Cre and CAG-CATZ constructs, using PCR primers and conditions detailed in Methods. Tissue DNA then was analyzed, as detailed in Fig. 1, for amplification of the recombination-dependent 690-bp fragment of CAG-CATZ, versus $\beta$-casein as a positive control.

dent recombination, all eight littermates were analyzed by whole-organ X-gal staining of heart, liver, lung, skeletal muscle (quadriceps), and spleen (Fig. 3). The induction of LacZ activity was specific to myocardium (blue) and was contingent on the $\alpha \mathrm{MyHC}^{-C r e}{ }^{+} / \mathrm{CAG}-\mathrm{CATZ}{ }^{+}$genotype (Fig. $3 \mathrm{~A}$, versus Fig. 3, $B-D)$. Because all organs tested in $\mathrm{CAG}-\mathrm{CATZ}^{+}$mice contain substantial CAT activity, the expression of LacZ selectively in myocardium cannot be ascribed to tissue-restricted transcription of the Cre-dependent reporter gene. Conversely, CAT activity in myocardium was reduced $\sim 90 \%$ in $\alpha \mathrm{MyHC}$ $\mathrm{Cre}^{+} / \mathrm{CAG}-\mathrm{CATZ}^{+}$mice, relative to expression in mice harboring CAG-CATZ alone (data not shown). A localized region of X-Gal staining extrinsic to the lung in Fig. $3 A$ is consistent with the previously noted activity of the $\alpha \mathrm{MyHC}$ promoter in pulmonary veins $(21)$.

To substantiate that Cre-dependent recombination in fact had occurred in ventricular myocytes themselves, induction of LacZ protein in myocytes was corroborated by both histochemical staining (Fig. 4) and by immunolocalization (not shown). Roughly $90 \%$ of ventricular myocytes were LacZ-positive, for the specific strain and time point illustrated in Fig. $4 C$. Other $\alpha \mathrm{MyHC}$-Cre strains resulted in differing degrees of LacZ activation (e.g., Fig. $4 \mathrm{D}$ ), which were unrelated to copy number (data not shown), consistent with insertional and positional effects or, potentially, differential methylation.

Adenoviral gene transfer to adult mouse myocardium in vivo. Because the $\alpha \mathrm{MyHC}$ promoter becomes transcription- ally active shortly after birth, in part resulting from the postnatal rise in thyroid hormone expression $(21,36)$, the foregoing experiments do not attest to the feasibility of Cre-mediated recombination in postmitotic ventricular muscle, which could be desirable or mandatory in other contexts. In preparation for adenoviral delivery of Cre/lox reagents to adult myocardium in vivo, pilot studies first were performed with a recombinant virus encoding a nuclear-localized LacZ protein under the control of the CMV promoter (Ad5/CMV/nls-LacZ). Given the small size of the adult mouse heart, a heart rate of 450-600 contractions per minute, and the objective of maximizing the reproducibility for gene delivery, injections were performed under direct visualization, after a median sternotomy, exteriorization of the heart, and transient immobilization. Five mice were injected with Ad5/CMV/nls-LacZ, two with the empty vector carrying only the CMV promoter (Ad5/CMV), two with diluent, and all nine mice were killed $7 \mathrm{~d}$ after injection (Fig. 5). To characterize the extent and reproducibility of gene delivery to adult mouse myocardium, four to five sections per heart were analyzed, $\sim 250 \mu \mathrm{m}$ apart. All hearts injected with Ad5/CMV/nls-LacZ were positive for LacZ, by X-gal staining, in three or more of these widely spaced sections (Fig. 5, $C$ and $D)$. No LacZ activity was detected, after injection of the diluent (Fig. 5, $A$ and $B$ ) or Ad5/CMV (Fig. 5, $E$ and $F$ ). The percentage of LacZ-positive nuclei averaged $36 \pm 11 \%(n=5)$ in the region of injection and ranged between 22 and 55\% (Fig. 5 $G)$. In these 7-d samples, a mononuclear infiltrate was present 

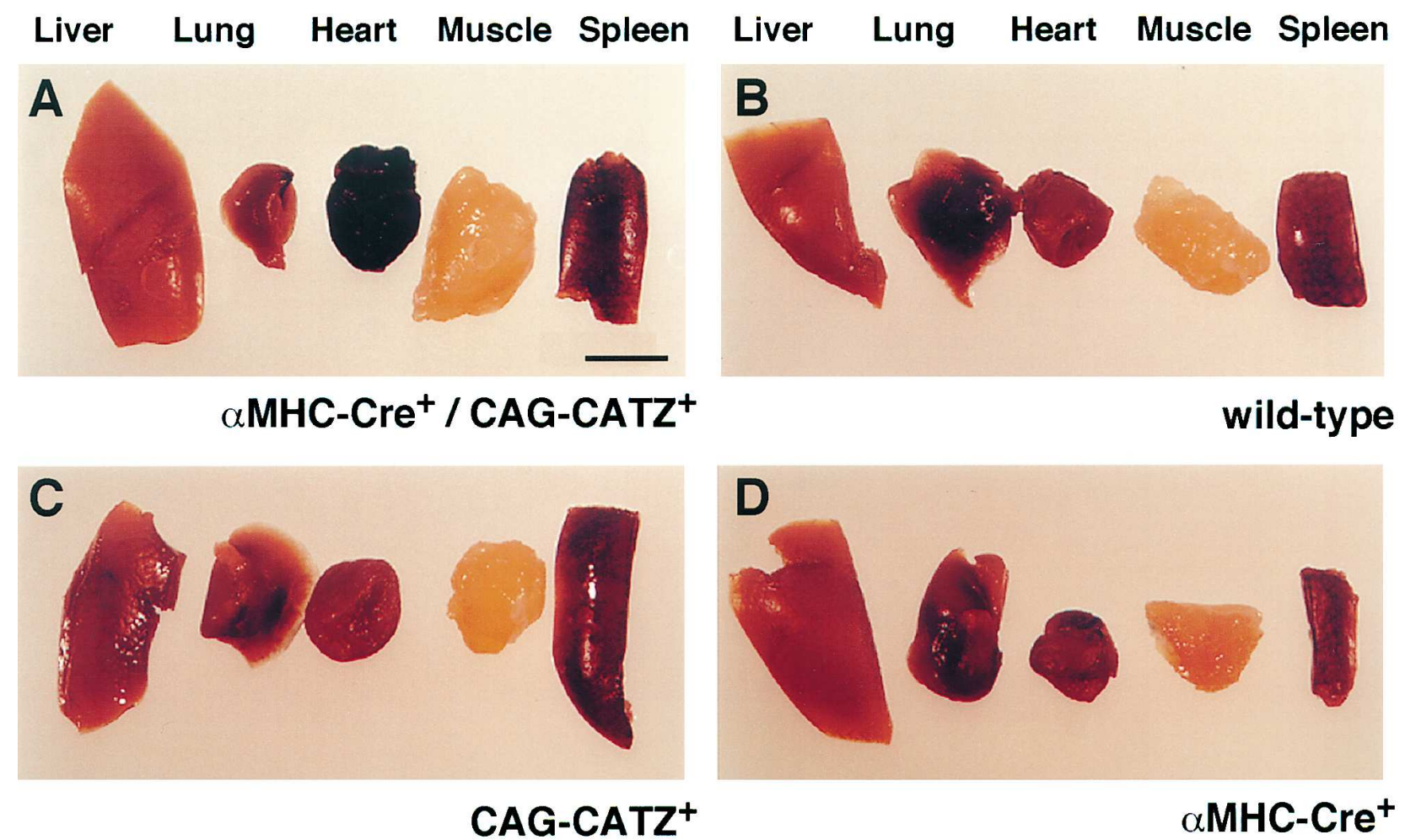

Figure 3. Whole-organ X-gal staining in littermates resulting from an $\alpha \mathrm{MyHC}$-Cre $\times$ CAG-CATZ cross similar to that shown in Fig. 2. Tissues from 6-wk-old animals were fixed and incubated for $3 \mathrm{~h}$ with $1 \mathrm{mg} / \mathrm{ml} \mathrm{X-gal.} \mathrm{LacZ} \mathrm{induction} \mathrm{was} \mathrm{evident} \mathrm{in} \mathrm{myocardium} \mathrm{of} \mathrm{double} \mathrm{transgenic}$ mice. Bar, $5 \mathrm{~mm}$.

in the area of injection for hearts injected either with Ad5/ $\mathrm{CMV} / \mathrm{nls}-\mathrm{LacZ}$ or Ad5/CMV, consistent with evidence that viral antigens (in addition to virally delivered protein) evoke an immune response (37).

Adenoviral delivery of Cre triggers recombination in cultured cardiac myocytes. As a second preparatory step-in vitro characterization of the adenoviruses bearing Cre and a Credependent reporter, for subsequent delivery to myocardium in vivo - neonatal rat ventricular myocytes were coinfected with viruses bearing the $\mathrm{CMV}$-driven Cre recombinase (AdCre) and a CMV-driven, recombination-dependent luciferase gene (AdMA19; Fig. 6, $A$ and $B$ ) (28). The moi ranged from 3 to 300 for each virus. Luciferase activity was contingent on the presence of both AdCre and AdMA19, verifying effective suppression of the reporter by the loxP-flanked spacer region inserted between the CMV promoter and luciferase gene. Luciferase activity was maximal at $15 \mathrm{PFU}$ per cell of AdCre and 150 PFU per cell of the reporter gene $\left(193 \pm 41 \times 10^{6}\right.$ light units per $\mu \mathrm{g}$ protein, 225 -fold greater than the luciferase produced in the absence of Cre at this concentration of AdMA19). Lowlevel expression of luciferase by this vector in the absence of Cre is ascribed to spontaneous recombination between the two homologous loxP sites (28). Luciferase activity decreased at higher total concentrations of virus than those illustrated, presumably because of cytopathic effects and/or promoter competition. Lysates of myocytes infected with AdCre, AdMA19, or both together, were used for Western blot analysis (Fig. 6 C). Luciferase protein was detected as a $62-\mathrm{kD}$ band, identical to the authentic protein standard, exclusively in cultures infected with AdCre and AdMA19 in tandem.
In vivo delivery of Cre triggers recombination in postmitotic ventricular muscle. To test for Cre-mediated recombination after adenoviral injection of adult mouse myocardium, mice were injected with AdCre alone $(n=2)$, AdMA19 $(n=3)$, or both in concert $(n=5)$. Mice were killed $7 \mathrm{~d}$ after injection, and luciferase activity was assayed (Fig. 7 E). Luciferase production was detected in all five hearts that received the Cre virus and Cre-dependent luciferase gene $(P=0.0001$ versus only AdCre; $P=0.0004$ versus only AdMA19); no significant production above the machine reagent blank was seen in any heart that received either virus alone.

To verify the site of Cre-mediated recombination, immunohistochemistry for luciferase protein in the injected hearts also was performed (Fig. 7, $A-D$ ). Two mice coinjected with AdCre plus AdMA19, and two with Ad5/CMV/nls-LacZ, were killed at $3 \mathrm{~d}$ to minimize the complication of infiltrating cells in the area of injection. Hearts were sectioned as described previously and were stained for luciferase with the antibody used for the Western blot shown in Fig. $6 C$. Localization of luciferase signal to terminally differentiated adult myocytes, among other cells, was confirmed in the area of injection for multiple adjacent sections.

Because Cre-mediated recombination of the coinjected reporter gene could, in theory, be contingent on the episomal state of the loxP-tagged viral genome, the CMV-driven Cre virus next was injected into apical myocardium of adult (9.5 wk) CAG-CATZ transgenic mice. Two mice were injected with the Cre virus and two with the empty CMV control; the hearts were harvested at $72 \mathrm{~h}$ for analysis by X-gal staining. Activation of the Cre-dependent lacZ gene was readily detected in 

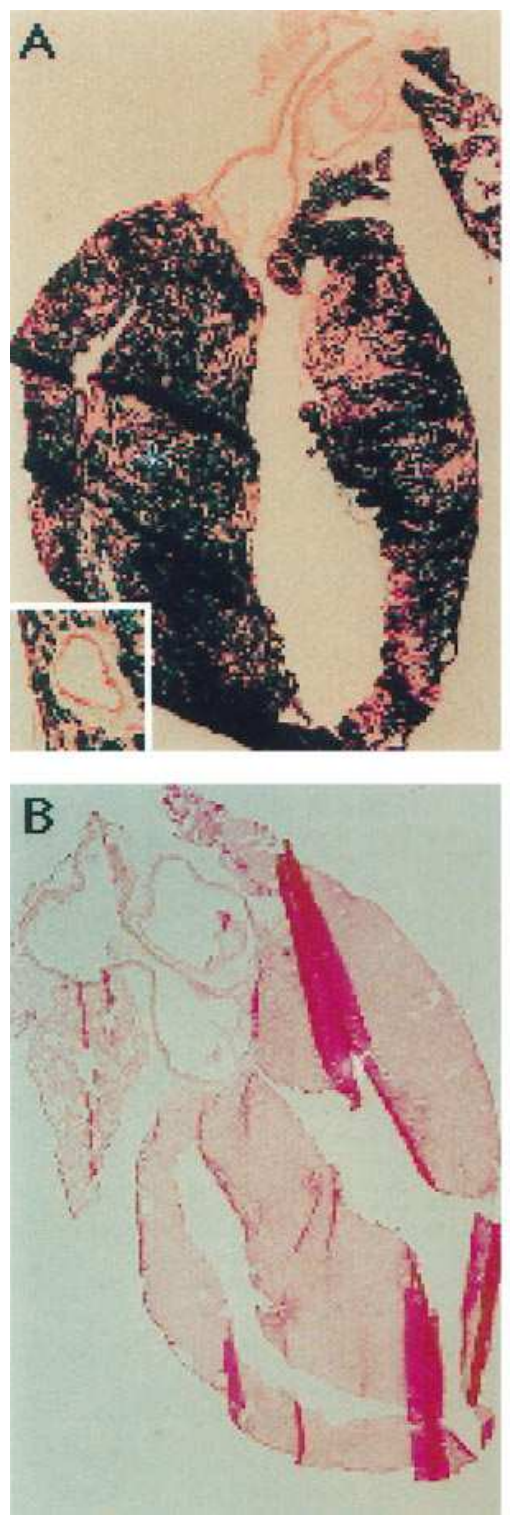
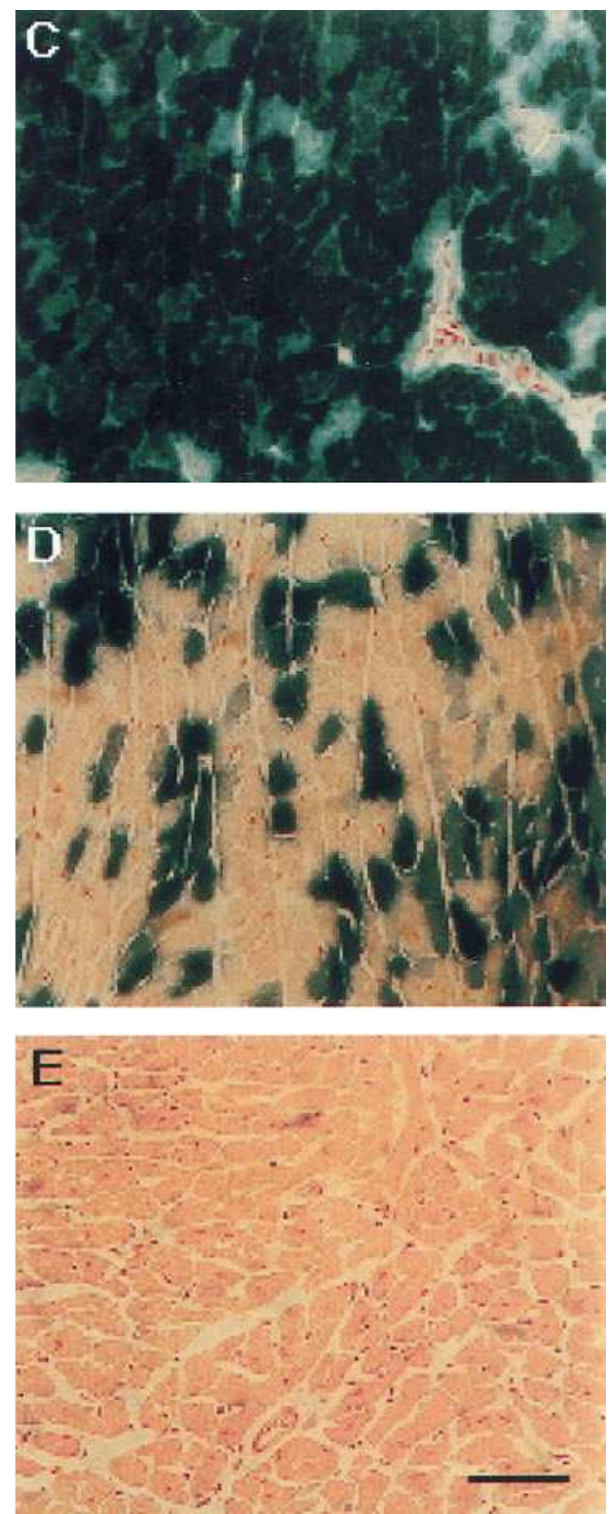

Figure 4. LacZ expression in myocardium of transgenic mice was analyzed by histochemical staining with X-Gal as substrate. LacZ induction was contingent on coinheritance of the $\alpha \mathrm{MyHC}-\mathrm{Cre}$ and CAG-CATZ genes and, by comparison to the prevalence in ventricular myocytes, was not detected in cardiac valves, coronary vessels, or the aorta. $(A, C$, and $D)$

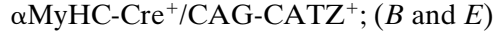

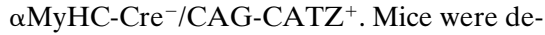
rived from $\alpha \mathrm{MyHC}-\mathrm{Cre}$ founder line 2176, except for the mouse illustrated in $D$, which was derived from a lower-prevalence founder line, 2177. Bar $A$ and $B, 250 \mu \mathrm{m} ; A$, inset $125 \mu \mathrm{m}$; $C-E, 50 \mu \mathrm{m}$. the adult ventricular myocytes (Fig. 8), establishing the feasibility for Cre-mediated recombination in this postmitotic cell background. Both mice that received the Cre virus expressed LacZ in the area injected, in eight or more sections spaced $\sim 250 \mu \mathrm{m}$ apart. The percentage of $\mathrm{LacZ}^{+}$cells ranged from 60 to $80 \%$ at the site injected and, thus, was at least equal to that achieved with Ad/CMV/nls-LacZ. $10 \times 40$ fields, totaling at least 2,000 cells, were scored for each mouse. No lacZ staining was detected in control animals injected with the empty virus. Thus, the efficacy for acutely induced recombination in postmitotic ventricular myocytes after local delivery of Cre approaches the degree of recombination achieved (more widely throughout the myocardium) by sustained expression of the $\alpha \mathrm{MyHC}-\mathrm{Cre}$ gene.

\section{Discussion}

The capacity to trigger site-specific gene recombination, with both temporal and spatial control, has obvious attractiveness for cardiovascular research. Driven by $\alpha \mathrm{MyHC}$ control sequences, the Cre transgene reported here catalyzes site-specific gene rearrangement selectively in cardiac myocytes. Moreover, the use of recombinant adenovirus as an acute delivery vehicle for Cre shows that recombination can be triggered by Cre even in postmitotic ventricular myocardium. Because a principal limitation of the available results was the absence of direct evidence that Cre-mediated recombination can be triggered in terminally differentiated, postmitotic cells, the importance of this investigation includes this proof of feasibility in vivo for this form of genetic switch in adult ventricular myocytes. Adenoviral delivery is especially well-suited for Cre-mediated recombination, given the capacity of recombinant adenoviruses for remarkably efficient gene transfer to ventricular myocytes $(38,39)$, skeletal muscle $(40)$, and other nonproliferating cells. More broadly, these findings suggest that a cardiac-restricted, drug-inducible Cre gene, as implemented for other proteins (41), could be used as an alternative means to trigger recombination selectively in adult heart. 

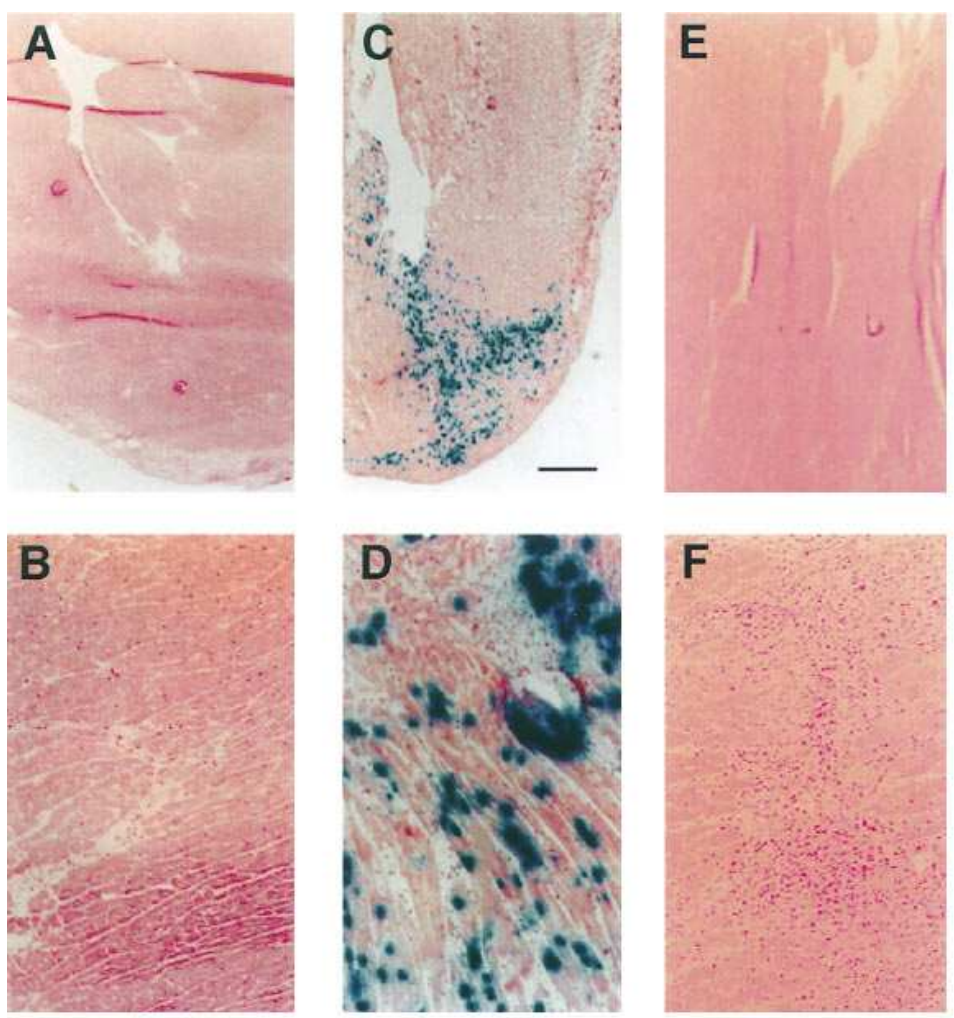

Ad5/CMV/nls-LacZ

vehicle

Ad5/CMV
G
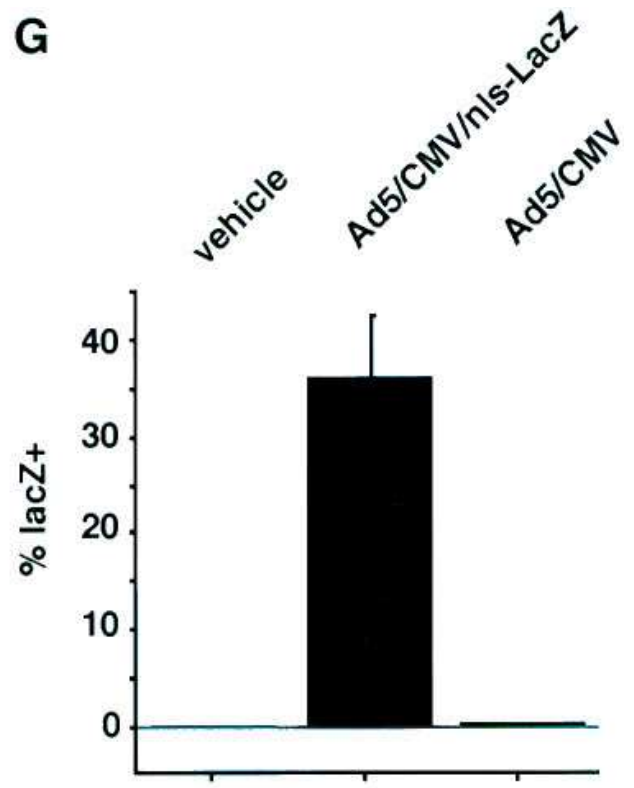

Figure 5. Adenoviral gene transfer to adult mouse myocardium in vivo. ( $A$ and $B$ ) Vehicle injection. ( $C$ and $D)$ Ad5/CMV/nls-LacZ. $(E$ and $F$ ) Ad5/CMV. $(G)$ The proportion of LacZ-positive cells is shown relative to total cell number on an immediately adjacent hematoxylin-eosinstained section, scoring a $900 \times 1,300 \mu \mathrm{m}$ area at the site of injection (range: 1,017-1,587 cells). For this experiment, LacZ expression is not contingent on Cre-mediated recombination. Bar $A, C$, and $E, 500 \mu \mathrm{m} ; B, D$, and $F, 100 \mu \mathrm{m}$.

Offsetting these advantages, the ability to study functional consequences after viral delivery of Cre shares with other in vivo gene transfer studies a need for short-term end points that can be analyzed before the onset of inflammation, or, to accommodate long-term measurements, less immunogenic vectors (42-44). The immunogenicity of Cre itself, a bacteriophage protein, may require alternative steps, such as induction of immune tolerance (45), immunodeficient recipients (46), or immunosuppression (43, 47-49). Modifications by which the efficiency of the present system might be further improved include using paired loxP sites which differ from each other to further decrease the theoretical incidence of spontaneous recombination, and improve the ratio of Cre-dependent to Creindependent target gene expression using this binary switch. Even in the absence of such modification, the induction resulting from addition of exogenous recombinase compares favorably with the inducibility of other binary systems for regulated gene expression both in vitro and in vivo.

Additional work will be needed to map, in detail, the onset of recombination in this system, including possible effects of $\alpha \mathrm{MyHC}$ transcription during cardiac organogenesis (50). Mosaicism for LacZ expression could result from strain-specific or integration site-specific patterns of transcription affecting either or both transgenes. Mosaicism here is also likely to result, at least in part, from properties of the CAG-CATZ reporter, driven by a $\beta$-actin promoter the transcription of which is known to decrease in the adult heart (51). By contrast, because the chimeric Cre-dependent gene actively expresses CAT in the absence of Cre, the observed penetrance of LacZ activity in the double transgenic mice is unlikely to be affected by methylation from having maintained the CAG-CATZ reporter in an unexpressed state. Two issues favoring the use of histological tests to define Cre-mediated recombination in cardiac muscle are the exceedingly high proportion of nonmyocytes in adult murine heart (19), which obviates simple reliance on PCR results, and possibly unequal expression of the Cre-dependent gene contingent on cell type, which would complicate extrapolations from myocardial homogenates. Potential advantages of the $\alpha \mathrm{MyHC}-\mathrm{Cre}$ transgene include the dependence of this promoter on thyroid hormone, suggesting one means to control the timing of recombination. Although this $\alpha \mathrm{MyHC}$ promoter has the capacity to drive transgenes with exceptional uniformity (52), line-to-line differences in mosaicism were found to occur, as anticipated, which could prove useful in the analysis of dose-dependent defects. Whereas high degrees of uniformity would be especially desirable for mutations of secreted proteins, defined degrees of mosaicism could prove advantageous in contexts including, but not necessarily limited to, cell-autonomous defects, i.e., as foreseen for growth factor receptors, intracellular signaling proteins, structural proteins, enzymes, and transcription factors. As reported recently (53), the use of single-copy transgenic 
A.

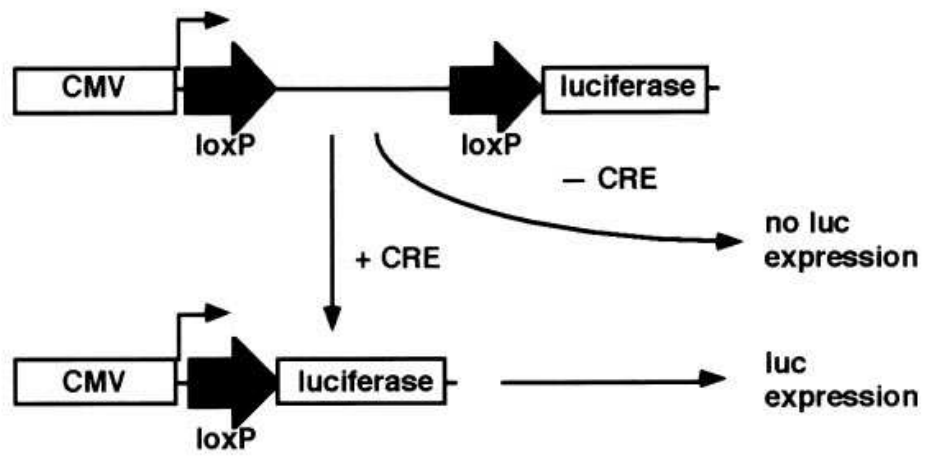

B.

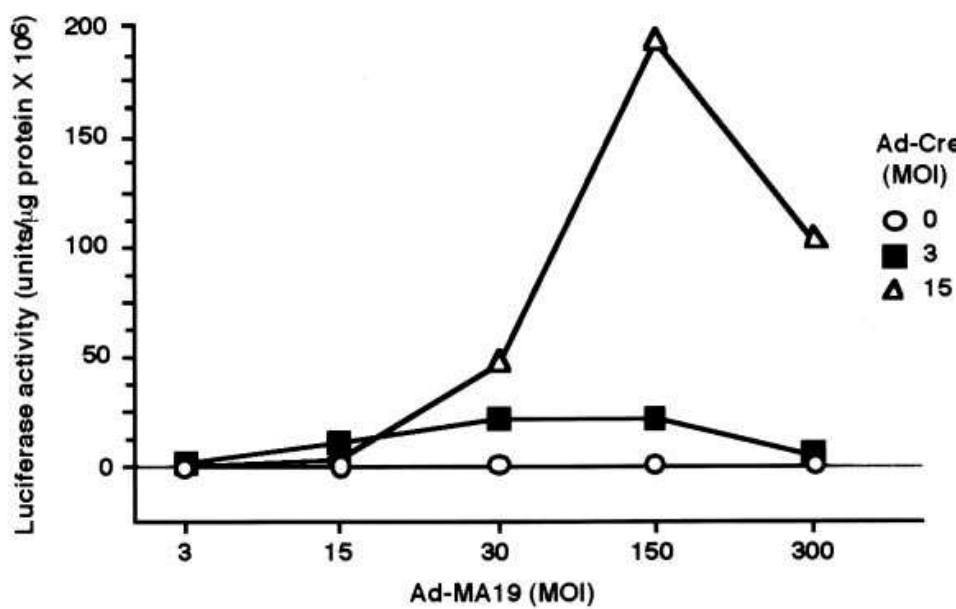

c.

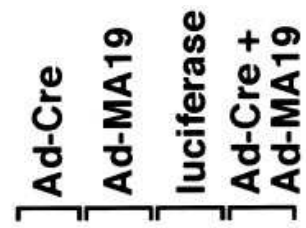

97.4

66

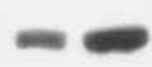

46
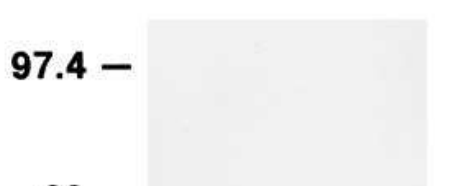

.

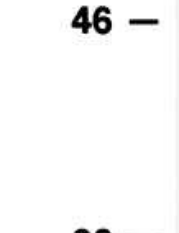

21.5 -

Figure 6. Adenoviral delivery of Cre in vitro. $(A)$ Schematic representation of AdMA19 (28). The spacer interposed between the loxP sites precludes efficient luciferase expression in the absence of the Cre recombinase. $(B)$ Luciferase induction in neonatal rat cardiac myocytes was dependent on coinfection with AdCre and AdMA19. Each determination is the mean of three separate cultures. The marked Cre-dependent increase in luciferase activity, with a decrease at higher moi, was seen in each of two independent experiments. $(C)$ Western blot analysis of Credependent luciferase expression.

mice with integration at a predetermined site provides a plausible means to override the heterogeneity inherent to conventional transgenic methods.

The experiments reported here concur with and extend a recent report, using viral delivery of Cre in vivo to activate a loxP-tagged transgene (54). In the latter study, recombination in neurons was extrapolated from PCR evidence for recombination after intracerebral injection, taken together with the presence of LacZ in neurons after parallel injections of virus encoding LacZ directly: thus, the identity of cell types undergoing recombination was left unanswered, for both the brain and the heart. By contrast, we have demonstrated Cre-dependent activation of the CAG-CATZ transgene, after adenoviral delivery to adult ventricular muscle cells in vivo. Thus, our findings redress the concern that postmitotic cells might be refractory to recombination produced by Cre.

For cardiovascular research, one a priori appeal of the Cre/ lox system is its unique ability to selectively eliminate certain genes from myocardium (or, in principle, any component of the cardiovascular system for which a suitably specific promoter exists), while preserving the remainder of the body in a wild-type state. Beyond merely surmounting the vexing problem of embryonic or early postnatal lethality, such specificity also provides a much-needed means to ensure that the consequences of a given gene deletion are a result of the protein's function in the affected cells, and not an untoward, confounding systemic, or indirect effect. Moreover, viral delivery of Cre provides a versatile means to generate an array of organ-specific knock-out mutations, as a rapid, less costly alternative to constructing and maintaining an array of tissue-specific Cre mice, perhaps with greater spatial precision than existing promoters would provide. The ability shown here, to evoke gene recombination selectively in myocardium, even in terminally differentiated, postmitotic ventricular muscle cells, expands dramatically the biological context in which a genetic approach to causal relations becomes plausible in cardiovascular research.

\section{Acknowledgments}

We thank F. Graham, S. O'Gorman, J. Robbins, and P. Vassali for the reagents cited; B. Boerwinkle, F. Ervin, P. Jackson, and J. Parker for technical assistance; M. Abdellatif, M.-J. Charng, and S. Akli for comments and suggestions; and R. Roberts for encouragement and support.

This work was supported in part by National Institutes of Health 


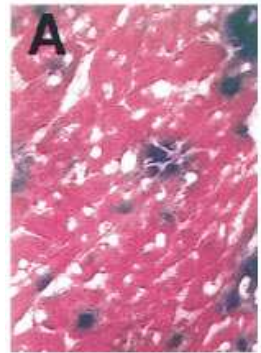

virus: nls-LacZ

antibody: none

(X-gal)
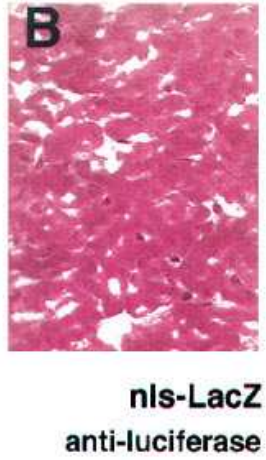

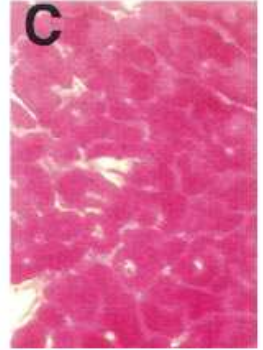

Cre + MA19 control

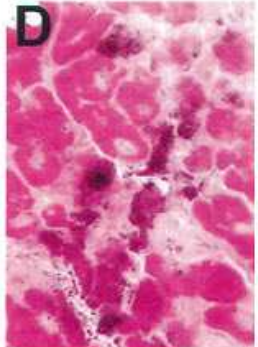

Cre + MA19 anti-luciferase
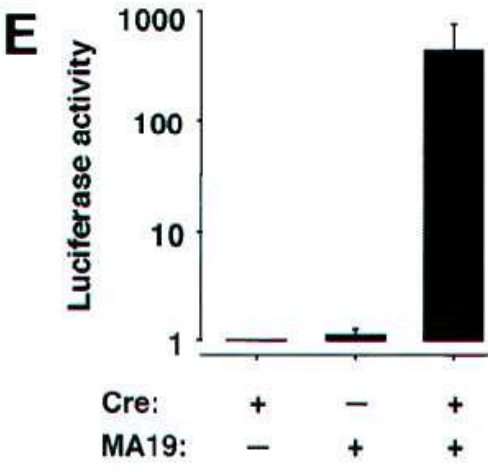

Figure 7. Adenoviral delivery of CMV-Cre triggers recombination in adult mouse myocardium in vivo. ( $A-D$ ) Adult mouse myocardium was injected with adenoviruses bearing CMV-LacZ or CMV-Cre plus the Cre-dependent luciferase gene, MA19, as shown. Luciferase activity in ventricular myocytes was demonstrated by immunoperoxidase staining $3 \mathrm{~d}$ after injection. $(E)$ Adult mouse myocardium was injected with adenoviruses bearing CMV-Cre or MA19 singly or in combination. Luciferase activity was analyzed $7 \mathrm{~d}$ after injection. Expression of the luciferase gene was contingent on codelivery of the Cre recombinase.
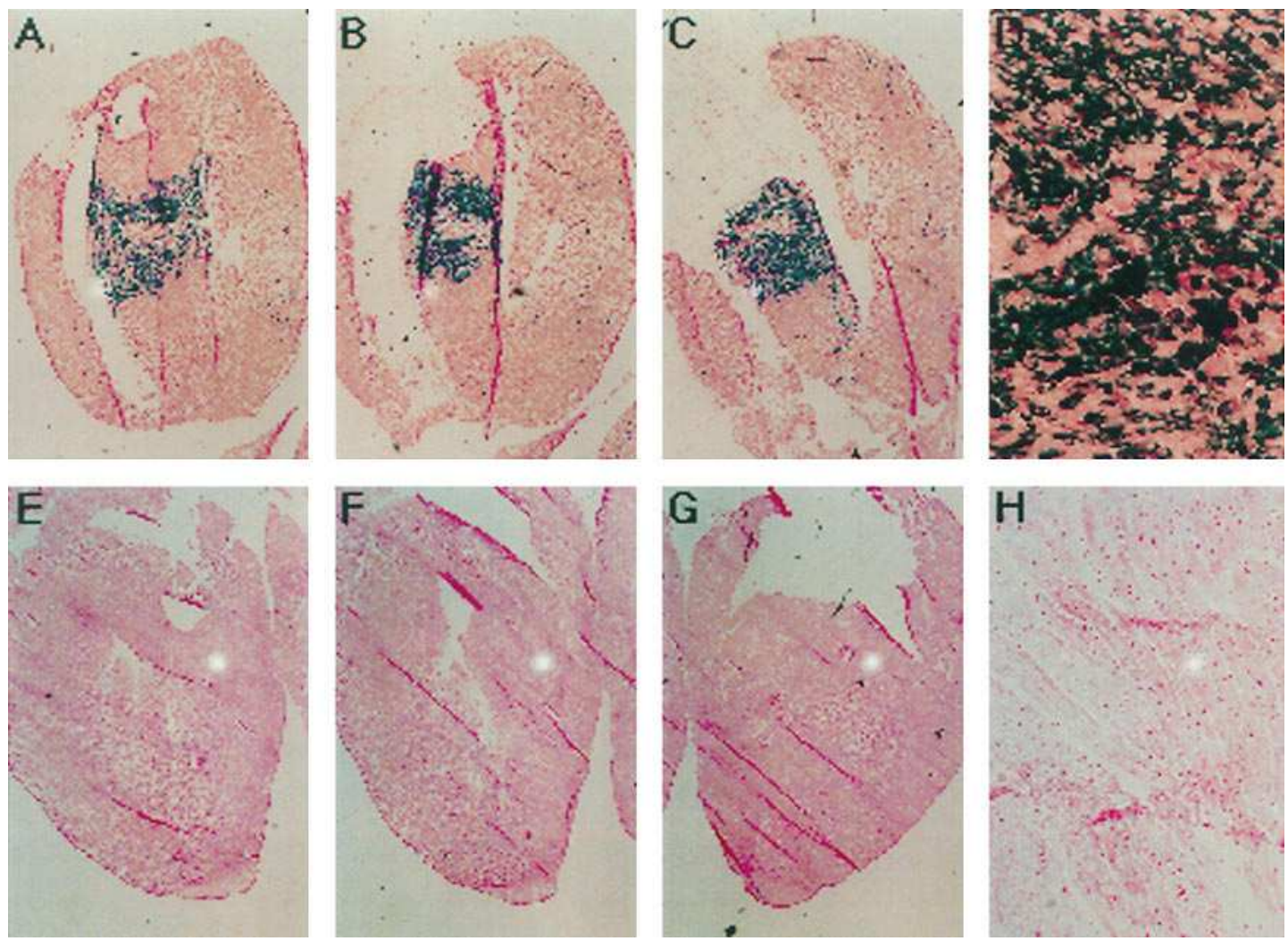

Figure 8. Adenoviral delivery of CMV-Cre triggers recombination in adult mouse myocardium of CAG-CATZ transgenic mice. Adult mouse myocardium was injected with adenovirus bearing CMV-Cre $(A-D)$ or the empty CMV control $(E-H)$, as shown, and was harvested $3 \mathrm{~d}$ after injection. Tissue was embedded in OCT solution (Triangle Biomedical Sciences), and frozen in isopentane over liquid $\mathrm{N}_{2}$; cryostat sections were prepared using a thickness of $6 \mu \mathrm{m}$. X-gal staining of cryostat sections was performed as described in Methods, except fixation was performed for $15 \mathrm{~min}$ at $0^{\circ} \mathrm{C}$, and staining was carried out for $12 \mathrm{~h}$ at $37^{\circ} \mathrm{C}$. Sections were counterstained with nuclear fast red. Representative low- and highpower fields are illustrated. Up to $80 \%$ of myocytes showed evidence of recombination in the region injected with Ad.CMV.Cre; no positive cells were detected in mice that received the control virus.

grants (R01 HL47567, R01 HL52555, P01 HL49953, P50 HL42267) to M.D. Schneider. P.A. Frenkel was funded by the National Heart, Lung, and Blood Institute Training Center for Molecular Cardiology (T32 HL07706).

\section{References}

1. Rajewsky, K., H. Gu, R. Kuhn, U.A.K. Betz, W. Muller, J. Roes, and F. Schwenk. 1996. Conditional gene targeting. J. Clin. Invest. 98:600-603. 
2. Lee, E.Y.H.P., C.Y. Chang, N.P. Hu, Y.C.J. Wang, C.C. Lai, K. Herrup, W.H. Lee, and A. Bradley. 1992. Mice deficient for Rb are nonviable and show defects in neurogenesis and haematopoiesis. Nature (Lond.). 359:288-294.

3. Letterio, J.J., A.G. Geiser, A.B. Kulkarni, N.S. Roche, M.B. Sporn, and A.B. Roberts. 1994. Maternal rescue of transforming growth factor-beta 1 null mice. Science (Wash. DC). 264:1936-1938.

4. Diebold, R.J., M.J. Eis, M. Yin, I. Ormsby, G.P. Boivin, B.J. Darrow, J.E. Saffitz, and T. Doetschman. 1995. Early-onset multifocal inflammation in the transforming growth factor $\beta 1$-null mouse is lymphocyte mediated. Proc. Natl. Acad. Sci. USA. 92:12215-12219.

5. O'Gorman, S., D.T. Fox, and G.M. Wahl. 1991. Recombinase-mediated gene activation and site-specific integration in mammalian cells. Science (Wash. DC). 251:1351-1355.

6. Walters, M.C., W. Magis, S. Fiering, J. Eidemiller, D. Scalzo, M. Groudine, and D.I. Martin. 1996. Transcriptional enhancers act in cis to suppress position-effect variegation. Genes Dev. 10:185-195.

7. Dymecki, S.M. 1996. Flp recombinase promotes site-specific DNA recombination in embryonic stem cells and transgenic mice. Proc. Natl. Acad. Sci. USA. 93:6191-6196.

8. Sauer, B., and N. Henderson. 1988. Site-specific DNA recombination in mammalian cells by the Cre recombinase of bacteriophage P1. Proc. Natl. Acad. Sci. USA. 85:5166-5170.

9. Fukushige, S., and B. Sauer. 1992. Genomic targeting with a positiveselection lox integration vector allows highly reproducible gene expression in mammalian cells. Proc. Natl. Acad. Sci. USA. 89:7905-7909.

10. Lakso, M., B. Sauer, B. Mosinger, Jr., E.J. Lee, R.W. Manning, S.H. Yu, K.L. Mulder, and H. Westphal. 1992. Targeted oncogene activation by site-specific recombination in transgenic mice. Proc. Natl. Acad. Sci. USA. 89:6232-6236.

11. Orban, P.C., D. Chui, and J.D. Marth. 1992. Tissue- and site-specific DNA recombination in transgenic mice. Proc. Natl. Acad. Sci. USA. 89:6861-6865.

12. Baubonis, W., and B. Sauer. 1993. Genomic targeting with purified Cre recombinase. Nucleic Acids Res. 21:2025-2029.

13. Sauer, B. 1993. Manipulation of transgenes by site-specific recombination: use of Cre recombinase. Methods Enzymol. 225:890-900.

14. Van, D.J., M. Fornerod, R.B. Van, and G. Grosveld. 1995. Cre-mediated site-specific translocation between nonhomologous mouse chromosomes. Proc. Natl. Acad. Sci. USA. 92:7376-7380.

15. Smith, A.J., S.M.A. De, B. Kwabi-Addo, A. Heppell-Parton, H. Impey, and P. Rabbitts. 1995. A site-directed chromosomal translocation induced in embryonic stem cells by Cre-loxP recombination. Nat. Genet. 9:376-385.

16. Metzger, D., J. Clifford, H. Chiba, and P. Chambon. 1995. Conditional site-specific recombination in mammalian cells using a ligand-dependent chimeric Cre recombinase. Proc. Natl. Acad. Sci. USA. 92:6991-6995.

17. Gu, H., J.D. Marth, P.C. Orban, H. Mossman, and K. Rajewsky. 1994. Deletion of a DNA polymerase beta gene segment in T cells using cell type-specific gene targeting. Science (Wash. DC). 265:103-106.

18. Kühn, R., F. Schwenk, M. Aguet, and K. Rajewsky. 1995. Inducible gene targeting in mice. Science (Wash. DC). 269:1427-1429.

19. Soonpaa, M.H., K.K. Kim, L. Pajak, M. Franklin, and L.J. Field. 1996. Cardiomyocyte DNA synthesis and binucleation during murine development. Am. J. Physiol. 40:H2183-H2189.

20. Wang, P., M. Anton, F.L. Graham, and S. Bacchetti. 1995. High frequency recombination between loxP sites in human chromosomes mediated by an adenovirus vector expressing Cre recombinase. Somatic Cell Mol. Genet. 21:429-441.

21. Subramaniam, A., W.K. Jones, J. Gulick, S. Wert, J. Neumann, and J. Robbins. 1991. Tissue-specific regulation of the alpha-myosin heavy chain gene promoter in transgenic mice. J. Biol. Chem. 266:24613-24620.

22. Abdellatif, M., W.R. MacLellan, and M.D. Schneider. 1994. p21 Ras as a governor of global gene expression. J. Biol. Chem. 269:15423-15426.

23. Araki, K., M. Araki, J. Miyazaki, and P. Vassalli. 1995. Site-specific recombination of a transgene in fertilized eggs by transient expression of Cre recombinase. Proc. Natl. Acad. Sci. USA. 92:160-164.

24. Taketo, M., A.C. Schroeder, L.E. Mobraaten, K.B. Gunning, G. Hanten, R.R. Fox, T.H. Roderick, C.L. Stewart, F. Lilly, C.T. Hansen, and P.A. Overbeek. 1991. FVB/N: an inbred mouse strain preferable for transgenic analyses. Proc. Natl. Acad. Sci. USA. 88:2065-2069.

25. French, B.A., W. Mazur, N.M. Ali, R.S. Geske, J.P. Finnigan, G.P. Rodgers, R. Roberts, and A.E. Raizner. 1994. Percutaneous transluminal in vivo gene transfer by recombinant adenovirus in normal porcine coronary arteries, atherosclerotic arteries, and two models of coronary restenosis. Circulation. 90:2402-2413.

26. Bett, A.J., W. Haddara, L. Prevec, and F.L. Graham. 1994. An efficient and flexible system for construction of adenovirus vectors with insertions or deletions in early regions 1 and 3. Proc. Natl. Acad. Sci. USA. 91:8802-8806.

27. Graham, F.L., and L. Prevec. 1991. Manipulation of adenovirus vectors. In Gene Transfer and Expression Protocols. Vol. 7. E. J. Murray, editor. Humana Press, Inc., Totowa, NJ. 109-127.

28. Anton, M., and F.L. Graham. 1995. Site-specific recombination mediated by an adenovirus vector expressing the Cre recombinase protein: a molecular switch for control of gene expression. J. Virol. 69:4600-4606.
29. Michael, L.H., M.L. Entman, C.J. Hartley, K.A. Youker, J. Zhu, S.R. Hall, H.K. Hawkins, K. Bernes, and C.M. Ballantyne. 1995. Myocardial ischemia and reperfusion: a murine model. Am. J. Physiol. 269:H2147-H2154.

30. Brand, T., W.R. MacLellan, and M.D. Schneider. 1993. A dominantnegative receptor for type-beta transforming growth factors created by deletion of the kinase domain. J. Biol. Chem. 268:11500-11503.

31. Eustice, D.C., P.A. Feldman, P.A.M. Colberg, R.M. Buckery, and R.H. Neubauer. 1991. A sensitive method for the detection of beta-galactosidase in transfected mammalian cells. Biotechniques. 11:739-740.

32. Bradford, M.A. 1976. A rapid and sensitive method for the quantitation of microgram quantities of protein utilizing the principle of protein-dye binding. Anal. Biochem. 72:248-254.

33. Seed, B., and J.Y. Sheen. 1988. A simple phase-extraction assay for chloramphenicol acyltransferase activity. Gene (Amst.). 67:271-277.

34. Ausubel, F.M., R. Brent, R.E. Kingston, D.D. Moore, J.G. Seidman, J.A. Smith, and K. Struhl. 1994. Current Protocols in Molecular Biology. John Wiley \& Sons, Inc., New York.

35. Hogan, B., R. Beddington, F. Costantini, and E. Lacy. 1994. Manipulating the Mouse Embryo: A Laboratory Manual. Cold Spring Harbor Laboratory, Cold Spring Harbor, NY. 497 pp.

36. Subramaniam, A., J. Gulick, J. Neumann, S. Knotts, and J. Robbins. 1993. Transgenic analysis of the thyroid-responsive elements in the alpha-cardiac myosin heavy chain gene promoter. J. Biol. Chem. 268:4331-4336.

37. Yang, Y., K.U. Jooss, Q. Su, H.C.J. Ertl, and J.M. Wilson. 1996. Immune responses to viral antigens versus transgene product in the elimination of recombinant adenovirus-infected hepatocytes in vivo. Gene Ther. 3:137-144.

38. Kirshenbaum, L.A., W.R. MacLellan, W. Mazur, B.A. French, and M.D. Schneider. 1993. Highly efficient gene transfer to adult rat ventricular myocytes by recombinant adenovirus. J. Clin. Invest. 92:381-387.

39. Kass-Eisler, A., E. Falck-Pedersen, M. Alvira, J. Rivera, P.M. Buttrick, B.A. Wittenberg, L. Cipriani, and L.A. Leinwand. 1993. Quantitative determination of adenovirus-mediated gene delivery to rat cardiac myocytes in vitro and in vivo. Proc. Natl. Acad. Sci. USA. 90:11498-11502.

40. Stratford-Perricaudet, L.D., I. Makeh, M. Perricaudet, and P. Briand. 1992. Widespread long-term gene transfer to mouse skeletal muscles and heart. J. Clin. Invest. 90:626-630.

41. Fishman, G.I., M.L. Kaplan, and P.M. Buttrick. 1994. Tetracycline-regulated cardiac gene expression in vivo. J. Clin. Invest. 93:1864-1868.

42. Leiden, J.M. 1995. Gene therapy-promise, pitfalls, and prognosis. $N$. Engl. J. Med. 333:871-873.

43. Fisher, K.J., H. Choi, J. Burda, S.J. Chen, and J.M. Wilson. 1996. Recombinant adenovirus deleted of all viral genes for gene therapy of cystic fibrosis. Virology. 217:11-22.

44. Kochanek, S., P.R. Clemens, K. Mitani, H.H. Chen, S. Chan, and C.T. Caskey. 1996. A new adenoviral vector: replacement of all viral coding sequences with $28 \mathrm{~kb}$ of DNA independently expressing both full-length dystrophin and beta-galactosidase. Proc. Natl. Acad. Sci. USA. 93:5731-5736.

45. Gilgenkrantz, H., D. Duboc, V. Juillard, D. Couton, A. Pavirani, J.G. Guillet, P. Briand, and A. Kahn. 1995. Transient expression of genes transferred in vivo into heart using first-generation adenoviral vectors: role of the immune response. Hum. Gene Ther. 6:1265-1274.

46. Yang, Y., and J.M. Wilson. 1996. CD40 ligand-dependent T cell activation: requirement of B7-CD28 signaling through CD40. Science (Wash. DC). 273:1862-1864.

47. Kass-Eisler, A., E. Falckpedersen, D.H. Elfenbein, M. Alvira, P.M. Buttrick, and L.A. Leinwand. 1994. The impact of developmental stage, route of administration and the immune system on adenovirus-mediated gene transfer. Gene Ther. 1:395-402.

48. Yang, Y.P., Q. Su, I.S. Grewal, R. Schilz, R.A. Flavell, and J.M. Wilson. 1996. Transient subversion of CD40 ligand function diminishes immune responses to adenovirus vectors in mouse liver and lung tissues. $J$. Virol. 70:6370-6377.

49. Yang, Y., G. Trinchieri, and J.M. Wilson. 1995. Recombinant IL-12 prevents formation of blocking IgA antibodies to recombinant adenovirus and allows repeated gene therapy to mouse lung. Nat. Med. 1:890-893.

50. Lyons, G.E., S. Schiaffino, S. Sassoon, P. Barton, and M. Buckingham. 1990. Developmental regulation of myosin gene expression in normal mouse cardiac muscle. J. Cell Biol. 111:2427-2436.

51. Sands, A.T., T.N. Hansen, F.J. Demayo, L.A. Stanley, L. Xin, and R.J. Schwartz. 1993. Cytoplasmic beta-actin promoter produces germ cell and preimplantation embryonic transgene expression. Mol. Reprod. Dev. 34:117-126.

52. Soonpaa, M.H., G.Y. Koh, M.G. Klug, and L.J. Field. 1994. Formation of nascent intercalated disks between grafted fetal cardiomyocytes and host myocardium. Science (Wash. DC). 264:98-101.

53. Bronson, S.K., E.G. Plaehn, K.D. Kluckman, J.R. Hagaman, N. Maeda, and O. Smithies. 1996. Single-copy transgenic mice with chosen-site integration. Proc. Natl. Acad. Sci. USA. 93:9067-9072.

54. Wang, Y., L.A. Krushel, and G.M. Edelman. 1996. Targeted DNA recombination in vivo using an adenovirus carrying the Cre recombinase gene. Proc. Natl. Acad. Sci. USA. 93:3932-3936. 